\title{
Zn in vegetables: A review and some insights
}

\author{
Koe Wei Wong ${ }^{1}$, Chee Kong Yap ${ }^{*}$, Rosimah Nulit ${ }^{1}$, Hishamuddin Omar ${ }^{1}$, Ahmad Zaharin Aris ${ }^{2}$, Wan Hee Cheng ${ }^{3}$, Mohd Talib Latif ${ }^{4}$ and \\ Chee Seng Leow ${ }^{5}$ \\ ${ }^{1}$ Department of Biology, Faculty of Science, Universiti Putra Malaysia, 43400 UPM Serdang, Selangor Malaysia \\ ${ }^{2}$ Department of Environmental Sciences, Faculty of Environmental Studies, Universiti Putra Malaysia, 43400 UPM Serdang, Selangor Malaysia \\ ${ }^{3}$ Inti International University, Persiaran Perdana BBN, 71800 Nilai, Negeri Sembilan, Malaysia \\ ${ }^{4}$ School of Environmental and Natural Resource Sciences, Faculty of Science and Technology, Universiti Kebangsaan Malaysia, 43600 Bangi, Selangor, Malaysia \\ ${ }^{5}$ Humanology Sdn Bhd, 73-3 Amber Business Plaza, Jalan Jelawat 1, 56000 Kuala Lumpur, Malaysia
}

\begin{abstract}
$\mathrm{Zn}$ is an important element in both industrial and biological sense. The great industrial importance of $\mathrm{Zn}$ has made this element a potential hazard to vegetable consuming humans. In this review, the important biological role of $\mathrm{Zn}$ and the human $\mathrm{Zn}$ dietary requirement as well as its toxicity are discussed. The $\mathrm{Zn}$ in various commonly consumed vegetables have also been reviewed. Based on a range to previous studies, it is confirmed that human activities such as metal mining and smelting as well as the application of manure fertilizer could contribute to $\mathrm{Zn}$ enrichment in both cultivation soil and the vegetable tissues. $\mathrm{Zn}$ in vegetable tissues also been discovered to have a strong and positive correlation with some element such as K, Fe, Mn and Cd. Due to Zn's industrial importance, it will always be a possibility of the occurrence of high $\mathrm{Zn}$ enrichment due to anthropogenic activities. Despite the biological importance, the constant monitoring of $\mathrm{Zn}$ in various food crops should not be neglected.
\end{abstract}

\section{Background}

The ability of human to discover and utilize natural heavy metal resources has been an indispensable factor in advancement of human civilization. The term "heavy metal" can be scientifically defined as the metal (e.g. copper, zinc, iron, cadmium, lead as well as various rare earth elements) and metalloid (e.g. arsenic) elements comprised in Groups 3 to 16 that are in periods 4 and greater in periodic table [1]. Ecological and human health risks is imminent due to continuous and chronic exposure of these elements [2,3]. Since metals are exists in form of chemical element, these metal and metal containing compounds are non-biodegradable and may accumulate and magnified in concentration up to harmful level along food chain [4,5]. The ecological and biological impact of these elements has been element specific and vary due to their chemical property and their chemical forms [6].

Zinc is an essential trace element that poses great importance in human dietary nutrition and health [7-9]. Therefore, it is known to be the second most abundant trace metal in human body after iron [9]. It is consisting 2-4 $\mathrm{g}$ within a human body mass with plasma concentration of $12-16 \mu \mathrm{M}$ [8]. The role of zinc on human health was originally observed and reported by Prasad et al. [10]. Since there is no specialized $\mathrm{Zn}$ storage system in human body, daily intake of $\mathrm{Zn}$ is necessary to maintain a steady state [8].

The objective of this review is to summarize the role of $\mathrm{Zn}$ in human physiology, the hazard of its enrichment and its appearance in commonly consumed vegetables.

\section{Human zinc dietary requirement}

The human zinc diet can be affected by the many factors. One of the factors is the type of food consumed. The resorption of $\mathrm{Zn}$ will be poorer from vegetarian foods in comparison of meat diet [8]. This is due to the chelation of zinc by non-digestible plant ligands such as dietary fibers, phytates and lignin [9].The appearance of other cations could also affect zinc availability. The resorption could also be reduced by increased bivalent cations, such as iron, cadmium, nickel, calcium, magnesium and copper $[9,11,12]$.

The recommended daily intake of zinc is dependent to several factors: age, sex, weight and the phytate content of diet [9]. The recommended values are also differing in each country and international regulatory organizations. The United States Food and Nutrition Board recommended daily intake of $11 \mathrm{mg}$ and $8 \mathrm{mg}$ for adult male and female respectively [13]. German Society of Nutrition's recommendation was set at $10 \mathrm{mg}$ and $7 \mathrm{mg}$ for adult male and female respectively [9]. Due to their impact on zinc availability to human diet, the dietary phytate must not be ignored in assessing zinc bioavailability to human. World Health Organization categorized the potential absorption efficiency of zinc, per phytate zinc molar ratio into three groups; high $(<5)$, moderate $(5-15)$ and low (>15) [14]. European Food Safety Authority (EFSA) have also made similar categorization according to dietary phytate intake [15].

Due to the difference of dietary zinc requirement by ages, sex, weight and phytate ingestion $[9,14,15]$. These factors must be taken consideration when the potential health risks of dietary zinc be assessed. The assessment of zinc related health risks must be built upon relevant localized data. The average bodyweight and food ingestion behavior across populations may be vastly different according to their religion,

*Correspondence to: Chee Kong Yap, Department of Biology, Faculty of Science, Universiti Putra Malaysia, 43400 UPM Serdang, Selangor Malaysia, E-mail: yapckong@hotmail.com

Received: January 19, 2019; Accepted: February 04, 2019; Published: February 08, 2019 
ethnicity and their individuals' societal norms. These differences must be taken account when health risk assessment will be done.

\section{Biological roles and health benefits}

Zinc has been known to be essential to multiple crucial biological processes. Zinc is a major component of protein ligands, it was discovered to present in approximately 3000 human proteins based on zinc signature motif in protein sequences [16-19]. The amount of zinc proteins in human zinc proteome will even be larger when additional functions of zinc in regulation [20]. Zinc is also involving in various cellular functions.

One of the roles of zinc playing in human biology is immunity [21,22]. Zinc deficiency can result in immunodeficiency [8]. Zinc ions are crucial element in the regulation of intracellular signaling pathway in innate and adaptive immune cells [21]. Immune systems is known to be susceptible to alteration in zinc levels and every immunological response by human body is related to zinc in varying extend [9]. There are two immunological mechanisms in human physiology; innate and adaptive immunity. Innate immunity is the first line of human biological defense countering various forms of pathogens. Innate immunity of human consists of polymorphonuclear cells (PMNs), macrophages, and natural killer cell (NK). Zinc deficiency is associated to reduced PMN chemotaxis and phagocytosis. Deficiency as well as excess of zinc could also inhibit the activity of nicotinamide adenine dinucleotide phosphate (NADPH) oxidase, which functions to destroy pathogens after it was phagocyted $[23,24]$. Chelation-free zinc was also be observed to abolish the formation of neutrophil extracellular traps (NETs) in vitro. This is a matrix of DNA, chromatin, and granule proteins that capture extracellular pathogenic protein [25]. Zinc also plays a role in the process of adhesion of monocytes to endothelial cells. In the context of human umbilical endothelial cells, its zinc levels were shown as inhibitive to monocyte adhesion to endothelial cells. It was suggested as one of the key factors in the early stages of antherogenesis [26]. Zinc is also heavily involved in production and signaling of various inflammatory cytokines in variety of cells [27]. Overweight and obese adults with low dietary zinc intakes were observed to have lower plasma zinc concentration, intracellular zinc content and intracellular free zinc levels. Upregulated IL- $1 \alpha$, IL- $1 \beta$ and IL- 6 genes were also observed for these patients in comparison of those with sufficient zinc intake [28]. Besides these aforementioned cytokines, zinc deficiencies in humans also influencing the production of IL-2 and TNF- $\alpha$ [29]. The supplementation of zinc to patients caused decreased expression of TNF- $\alpha$, IL- $1 \beta$ in their phytohemagglutinin-p-stimulated mononuclear cells, showing their antagonistic relationship. While zinc supplementation was showed to increase the expression of IL-2 and IL-2Ra [30]. Zinc deficiency is also associated with the damage of lysosome integrity causing the activation of MLRP3 (ACHT, LRR, and PYD domains-containing protein 3 ) inflammasome, leading to IL- $1 \beta$ activation [31]. Zinc deficiency causes severe impairment of human immune function. On the flip side, excessive zinc could also provoke similar immune impairment as zinc deficiency does. Excessive zinc could cause the suppression of $\mathrm{T}$ and $\mathrm{B}$ cell function, overload of $\mathrm{T}_{\text {reg }}$ cell and direct activation of macrophages [21]. Worse inflammatory profile was observed in zinc deficient institutionalized elders [32].

Besides regulating immunity related cytokine and suppress of inflammation, zinc also have their importance in the function of lipid and glucose metabolism, reduction of oxidative stress, regulation and formation of insulin [33]. The formation of reactive oxygen species (ROS) and also the reactive nitrogen species could be inhibited by physiological concentration of zinc $[34,35]$. There are a few factors contributing on the antioxidation effect of zinc. These was achieved by: (i) regulate oxidant production and metal-induced oxidative damage; (ii) associating itself with sulfur in protein cysteine cluster, from which metals can be released by nitric oxide, peroxides, oxidized glutathione and other thiol species; (iii) induction of metallothionein, a zinc binding protein that can act as oxidant scavenger; (iv) regulating glutathione metabolism and protein thiol redox status; and (v) regulating redox signaling directly as well as indirectly [36]. As a cofactor of antioxidant enzyme $\mathrm{Cu}, \mathrm{Zn}$-super oxide dismutase (SOD1), zinc is an important factor in keeping $\mathrm{Cu}, \mathrm{Zn}$-SOD functionable [37]. Glutathione peroxidase expression could also be increased by zinc supplementation [38]. It must be noted that zinc does not always antioxidative, prooxidative properties could also be dominant when intracellular zinc levels are high. Zinc oxide nanoparticle has been shown to increase oxidative stress in 3T3-L1 adipocyte in a dose dependent manner despite increasing the expression of antioxidant enzymes [39,40]. Higher dose of zinc oxide nanoparticle was observed to severely increased oxidative stress at high doses $(10 \mathrm{mg} / \mathrm{kg})[41]$.

Tight interaction between zinc and adipose dysfunction is a major interest in lipid metabolism study [33]. It has been reported that zinc supplementation can results in reduced total cholesterol, LDL cholesterol and triglycerides; as well as increase in HDL cholesterol level in patients $[38,42]$. Zinc finger protein ZNF202, as the name suggest, is a zinc containing protein that are involving in HDL metabolism [43]. This proteins was suggested as a candidate susceptibility gene for human dyslipidemia [44]. Decrease in zinc plasma concentration has resulted in worse lipid profile in zinc deficient institutionalized elders [32]. Zinc status was tightly associated to adipose tissue in obesity and its pathologies. High fat intake has resulted in decrease of zinc level in adipose tissue of Wistar rats and is tightly related with excessive adiposity, inflammation, insulin resistance and potentially atherogenic changes [45].

Zinc is essential in normal synthesis, storage and secretion of insulin in pancreatic $\beta$ cells $[33,46]$. Zinc supplementation has been beneficial to the glucose homeostasis of diabetic patients [47] and vice versa [48]. This metal have been known to playing a role in glycolysis stimulation, gluconeogenesis inhibition and modulation of glucose in adipocytes [49]. The contribution of zinc in insulin biosynthesis and storage is by forming a hexamer with proinsulin molecules along with calcium. This proinsulin hexamer assembly could form a protective structure that protected some polypeptide chain from proteolytic cleavage, while leaving C-peptide segment of pro insulin exposed to processing enzymes. The alteration of solubility of proinsulin hexamer to insulin hexamer and subsequently crystalized insulin hexamers giving further protection of newly formed insulin chains and separating proinsulin from insulin as the conversion to insulin occurring. Insulin hexamers are also enjoys greater chemical and physical stability than its monomer counterpart [50]. Therefore, the formation and crystallization of proinsulin/insulin hexamer with zinc and calcium ions stabilizes insulin and protects it from degradation. Beside taking part in insulin biosynthesis, storage and crystallization, zinc is also known to be inhibitive to glucagon secretion [51]. Glucagon is a hormone that its function is opposite of insulin's. Zinc supplemented diabetic patients was resulted in elevated insulin and serum zinc coupled with reduced blood glucose, glucagon and glucose-6-phosphatase, indicating the role of zinc in physiological glucose regulation [52].

Zinc is also a key element in the growth and development of human. Zinc deficiency during embryogenesis may influence the final phenotype of all organs. Fetal growth may also influence by zinc 
restriction during pregnancy. Sufficient zinc supplementation reduced the risk of pre-term birth [53].

\section{Zinc toxicity to human}

Despite the apparent biological importance of zinc, acute as well as chronic exposure to overly high concentration of zinc could also bring detrimental impact to human health. The manifestation of acute zinc poisoning could include nausea, vomiting, diarrhea, fever and lethargy. While long term chronic exposure to excessive zinc levels could resulting in metabolic interference with other trace elements. Daily intake of 150-450 $\mathrm{mg}$ of zinc have been related to reduction of copper utilization, alteration of iron function, reduction of immune function, as well as the reduction of high-density lipoprotein (HDL) level [54,55]. Zinc has been discovered to have an antagonistic relationship with copper. Therefore, zinc has been utilized to treat Wilson disease, an autosomal recessive disorder of copper metabolism since 1960s. However, copper is still an essential element crucial for the survival of human being, imbalance in zinc intake may cause an induction of copper deficiency (hypocupremia) [14,56,57].

Chronic enriched zinc intakes could result in various chronic effects in gastrointestinal, hematological, and respiratory system along with alteration in cardiovascular and neurological systems of human [57]. Human subjects supplemented with $300 \mathrm{mg}$ zinc per day has been characterized to have elevated LDL cholesterol and reduced HDL cholesterol [58]. $\mathrm{Cu}, \mathrm{Zn}$ SOD antioxidant is very sensitive toward $\mathrm{Zn} / \mathrm{Cu}$ ratio changes in plasma. Zinc supplementation may result in excess of free radicals that are detrimental to plasma membrane. The competition between zinc and iron will also causing a decrease if serum ferritin and hematocrit concentration [57]

\section{$\mathrm{Zn}$ in vegetables}

Vegetable representing a significant portion of recommended human daily diet due to its richness in essential nutrients while low in fat, sodium and calories [59]. As discussed in previous section, $\mathrm{Zn}$ is considered as an essential element for human survival. However, an excess of it will jeopardize human health, causing health risk to human being. This review will present some of the recent studies that investigated the concentration of $\mathrm{Zn}$ in a variety of commonly consumed vegetables in several locales. These studies have been presented in Table 1.

$\mathrm{Zn}$ is essential not only to humans, but also to food crops themselves. There are a numerous studies that confirms the positive correlation of $\mathrm{Zn}$ in plant tissues and $\mathrm{Zn}$ in surrounding habitat [6062]. An experimental exposure of $5 \mathrm{mM}$ and $10 \mathrm{mM}$ of $\mathrm{Zn}$ to common bean, Phaseolus vulgaris, has revealed a positive $\mathrm{Zn}$ accumulation in consequence of the exposure [60]. Another study that samples common purslane Portulaca oleracea in Costa da caparica, Portugal, also revealed similar pattern of $\mathrm{Zn}$ accumulation. However, due to high Zn contamination in two of their sites, the P. oleracea from those sites were highly contaminated and consumption were deemed unsafe [61]. Ribwort plantain, Plantago lanceolata L., is a roadside and grassland flora that is widely used as food and herbal preparation in various countries. Drava et al. compared the $\mathrm{Zn}$ levels in P. lanceolata in a series of sites with varying anthropogenic characteristics. They revealed that

Table 1. Review of $\mathrm{Zn}$ concentrations and notable findings of previous studies

\begin{tabular}{|c|c|c|c|c|}
\hline Vegetable species & Zn concentration in vegetables & Findings & $\begin{array}{l}\text { Exposure concentrations/sample } \\
\text { collection site }\end{array}$ & Reference \\
\hline Common beans (Phaseolus vulgaris) & & $\begin{array}{l}\text { - Positive } \mathrm{Zn} \text { accumulation resulted from } \mathrm{Zn} \text { exposure. } \\
\text { - } \\
\text { - } \\
\text { Reduced } \mathrm{Zn} \text { during pods } \\
\text { Reduced phytic level }\end{array}$ & $5 \mathrm{mM}, 10 \mathrm{mM}$ & {$[60]$} \\
\hline Brassica juncea & & \multirow{2}{*}{$\begin{array}{l}\text { - B. juncea is more } \mathrm{Zn} \text { tolerant in the perspective of roo } \\
\text { damage and microelement homeostasis alteration. } \\
\text { - Oxidative components were predominant compared to } \\
\text { nitrosative components in root. }\end{array}$} & \multirow{2}{*}{$0-300 \mu \mathrm{M}$} & \multirow[b]{2}{*}[67]{} \\
\hline Brassica napus & & & & \\
\hline $\begin{array}{l}\text { Common } \\
\text { oleracea) }\end{array} \quad$ Purslane $\quad$ (Portulaca & & $\begin{array}{l}\text { - P. oleracea collected in two stations contaminated } \\
\text { with high concentration of } \mathrm{Zn} \text {. Consumption should be } \\
\text { avoided. }\end{array}$ & Costa da caparica, Portugal & {$[61]$} \\
\hline Wheat (Triticum aestivum L.) & & $\begin{array}{l}\text { - Oxidative stress was minimized, and root, shoot and } \\
\text { spike length were increased coupled with potassium. } \\
\text { - Enhancement of fresh and dry biomass coupled with } \\
\text { potassium } \\
\text { - Enhancement of photosynthetic pigment and osmolyte } \\
\text { regulator (proline, total phenolic and total carbohydrate), } \\
\text { coupled with potassium. } \\
- \text { K and Zn reduced MDA content, increased membrane } \\
\text { stability index. } \\
- \text { K and Zn improved antioxidant enzyme activities. }\end{array}$ & $200 \mathrm{ppm}$ & {$[68]$} \\
\hline Zucchini (Cucurbita pepo L.) & & $\begin{array}{l}\text { - Application of cow manure biochar reduced } \\
\text { bioavailability and translocation factor for heavy } \\
\text { metals, including } \mathrm{Zn} \text {. }\end{array}$ & NA & {$[78]$} \\
\hline $\begin{array}{l}\text { Ribwort plantain } \\
\text { (Plantago lanceolata } \text { L.) }\end{array}$ & $97.4-108.7 \mathrm{mg} / \mathrm{kg} \mathrm{dw}$ & $\begin{array}{l}-\mathrm{Cd}, \mathrm{Pb} \text { and } \mathrm{Zn} \text { concentrations in samples near mines and } \\
\text { smelting plants were up to } 15 \text { times above rural areas }\end{array}$ & $\begin{array}{l}\text { Genoa and province (Liguria, North- } \\
\text { Western Italy) }\end{array}$ & {$[62]$} \\
\hline $\begin{array}{l}\text { garlic (Allium sativum), leek } \\
\text { (A. tuberosum), celery (Apium } \\
\text { graveolens), cabbage (Brassica } \\
\text { oleracea), broccoli (B. var. italica), } \\
\text { chicory (Cichorium endivia), } \\
\text { taro (Colocasia esculenta), carrot } \\
\text { (Daucus carota), lettuce (Lactuca } \\
\text { sativum), pea (Pisum sativum) and } \\
\text { potato (Solanum tuberosum) }\end{array}$ & $3.87-25.50 \mathrm{mg} / \mathrm{kg}$ & $\begin{array}{l}\text { - Maximum } \mathrm{Zn} \text { level in celery stem was significantly } \\
\text { lower than permissible value of WHO/FAO. }\end{array}$ & $\begin{array}{l}\text { Xiguadi village, Guangdong, China } \\
\text { (Near Lechang } \mathrm{Pb} / \mathrm{Zn} \text { mine) }\end{array}$ & {$[79]$} \\
\hline
\end{tabular}




\begin{tabular}{|c|c|c|c|c|}
\hline Bracken & $\mu \mathrm{g} / 100 \mathrm{~g}$ & \multirow{11}{*}{$\begin{array}{l}\text { - The } \mathrm{Zn} \text { intakes from the } 11 \text { wild vegetables compared } \\
\text { with dietary reference intakes in the healthy Koreans } \\
\text { were } 1.4 \% \text { for } \mathrm{Zn} \text {, }\end{array}$} & \multirow{11}{*}{ Market purchased } & \multirow{11}{*}[80]{} \\
\hline Shepperd's purse & $568.31 \mu \mathrm{g} / 100 \mathrm{~g}$ & & & \\
\hline Wild Chive & $97.85 \mu \mathrm{g} / 100 \mathrm{~g}$ & & & \\
\hline Codonopsis lanceolata & $506.22 \mu \mathrm{g} / 100 \mathrm{~g}$ & & & \\
\hline Sedum & $125.76 \mu \mathrm{g} / 100 \mathrm{~g}$ & & & \\
\hline Wild parsley & $1110.33 \mu \mathrm{g} / 100 \mathrm{~g}$ & & & \\
\hline Butterbur & $250.37 \mu \mathrm{g} / 100 \mathrm{~g}$ & & & \\
\hline Chinese chive & $407.17 \mu \mathrm{g} / 100 \mathrm{~g}$ & & & \\
\hline Pimpinella brachycarpa & $233.58 \mu \mathrm{g} / 100 \mathrm{~g}$ & & & \\
\hline Fragrant edible wild aster & $686.32 \mu \mathrm{g} / 100 \mathrm{~g}$ & & & \\
\hline Spinach & $1338.79 \mu \mathrm{g} / 100 \mathrm{~g}$ & & & \\
\hline $\begin{array}{l}\text { Leaf vegetables (non-compositae } \\
\text { plants) }\end{array}$ & $8.4 \mathrm{mg} / \mathrm{kg}$ & \multirow{3}{*}{$\begin{array}{l}\text { - The } \mathrm{Zn} \text { in cultivation soil originated from chicken } \\
\text { manure }\end{array}$} & \multirow{3}{*}{$\begin{array}{l}\text { Closed greenhouse vegetable } \\
\text { production system in Nanjing, China }\end{array}$} & \multirow{3}{*}[72]{} \\
\hline Leaf vegetables (compositae plants) & $8.6 \mathrm{mg} / \mathrm{kg}$ & & & \\
\hline Other plants (non-leaf vegetables) & $3.3 \mathrm{mg} / \mathrm{kg}$ & & & \\
\hline Endive & $13.121 \mathrm{mg} / \mathrm{kg} \mathrm{FW}$ & \multirow{18}{*}{$\begin{array}{l}\text { - Smelting activity caused significant } \mathrm{Cd} \text { and } \mathrm{Zn} \text { pollution } \\
\text { in local soils } \\
-\mathrm{Zn} \text { concentration in soil is one of the factor influencing } \\
\mathrm{Cd} \text { accumulation in cabbage }\end{array}$} & \multirow{18}{*}{$\begin{array}{l}\text { North of Huludao Zinc Plant, Liaoning } \\
\text { Province, China }\end{array}$} & \multirow{18}{*}{ [71] } \\
\hline Spinach & $17.632 \mathrm{mg} / \mathrm{kg} \mathrm{FW}$ & & & \\
\hline Lettuce & $7.864 \mathrm{mg} / \mathrm{kg} \mathrm{FW}$ & & & \\
\hline Celery & $15.682 \mathrm{mg} / \mathrm{kg} \mathrm{FW}$ & & & \\
\hline Pakchoi & $10.112 \mathrm{mg} / \mathrm{kg} \mathrm{FW}$ & & & \\
\hline Cabbage & $7.967 \mathrm{mg} / \mathrm{kg} \mathrm{FW}$ & & & \\
\hline Garland chrysanthemum & $7.341 \mathrm{mg} / \mathrm{kg} \mathrm{FW}$ & & & \\
\hline Chinese cabbage & $4.389 \mathrm{mg} / \mathrm{kg} \mathrm{FW}$ & & & \\
\hline Eggplant & $2.467 \mathrm{mg} / \mathrm{kg} \mathrm{FW}$ & & & \\
\hline Green pepper & $2.411 \mathrm{mg} / \mathrm{kg} \mathrm{FW}$ & & & \\
\hline Cauliflower & $7.722 \mathrm{mg} / \mathrm{kg} \mathrm{FW}$ & & & \\
\hline Cucumber & $2.656 \mathrm{mg} / \mathrm{kg} \mathrm{FW}$ & & & \\
\hline Tomato & $1.544 \mathrm{mg} / \mathrm{kg} \mathrm{FW}$ & & & \\
\hline Green bean & $4.053 \mathrm{mg} / \mathrm{kg} \mathrm{FW}$ & & & \\
\hline Carrot & $9.447 \mathrm{mg} / \mathrm{kg} \mathrm{FW}$ & & & \\
\hline Onion & $21.801 \mathrm{mg} / \mathrm{kg} \mathrm{FW}$ & & & \\
\hline Potato & $10.767 \mathrm{mg} / \mathrm{kg} \mathrm{FW}$ & & & \\
\hline Radish & $8.553 \mathrm{mg} / \mathrm{kg} \mathrm{FW}$ & & & \\
\hline 30 strains of Amaranthus tricolor & 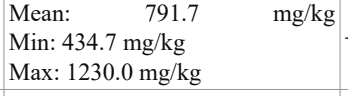 & - Strong positive relationship of $\mathrm{Zn}$ with $\mathrm{Fe}$ and $\mathrm{Mn}$ & NA & [70] \\
\hline Apple & $2.05 \mathrm{ppm}$ & \multirow{16}{*}{ - $\mathrm{Zn}$ was strongly and positively correlated with $\mathrm{Cd}$} & \multirow{16}{*}{$\begin{array}{l}\text { Purchased from market place in } \\
\text { Karachi }\end{array}$} & \multirow{16}{*}{ [69] } \\
\hline Muskmelon & $2.73 \mathrm{ppm}$ & & & \\
\hline Chiku & $5.11 \mathrm{ppm}$ & & & \\
\hline Papaya & $1.74 \mathrm{ppm}$ & & & \\
\hline Mango & $2.40 \mathrm{ppm}$ & & & \\
\hline Luffa & $2.50 \mathrm{ppm}$ & & & \\
\hline Bitterbourd & $1.98 \mathrm{ppm}$ & & & \\
\hline Onion & $0.83 \mathrm{ppm}$ & & & \\
\hline Garlic & $5.13 \mathrm{ppm}$ & & & \\
\hline Pumpkin & $3.51 \mathrm{ppm}$ & & & \\
\hline Indian squash & $3.22 \mathrm{ppm}$ & & & \\
\hline Cucumber & $3.22 \mathrm{ppm}$ & & & \\
\hline Brinjal & $3.52 \mathrm{ppm}$ & & & \\
\hline Lady's finger & $4.63 \mathrm{ppm}$ & & & \\
\hline Tomato & $2.45 \mathrm{ppm}$ & & & \\
\hline Chillies & $2.69 \mathrm{ppm}$ & & & \\
\hline Leafy vegetable (Contaminated area) & $11.327 \mathrm{mg} / \mathrm{kg} \mathrm{FW}$ & & \multirow{4}{*}{$\begin{array}{l}\text { Zhuzhou Smelter, Zhuzhou, Hunan } \\
\text { Province, China. }\end{array}$} & \multirow{4}{*}{ [63] } \\
\hline $\begin{array}{l}\text { Non-leafy vegetable (Contaminated } \\
\text { area) }\end{array}$ & $9.435 \mathrm{mg} / \mathrm{kg} \mathrm{FW}$ & & & \\
\hline $\begin{array}{l}\text { Leafy vegetable } \\
\text { (controlled area) }\end{array}$ & $3.679 \mathrm{mg} / \mathrm{kg} \mathrm{FW}$ & & & \\
\hline $\begin{array}{l}\text { Non-leafy vegetable } \\
\text { (controlled area) }\end{array}$ & $2.757 \mathrm{mg} / \mathrm{kg} \mathrm{FW}$ & & & \\
\hline $\begin{array}{l}\text { Bok Choy (Brassica campestris } \\
\text { L. ssp. chinensis Makino), Water } \\
\text { Spinach (Ipomoea aquatica } \\
\text { Forsk.), Shanghai green cabbage } \\
\text { (Brassica chinensis L.), leaf lettuce } \\
\text { (Lactuca sativa } \text { L. var. ramosa Hort.) }\end{array}$ & $\begin{array}{l}3.96 \mathrm{mg} / \mathrm{kg} \mathrm{FW} \text { (average of all } \\
\text { leafy vegetable investigated) }\end{array}$ & - below the food safety limits in China & Shanghai, China & [73] \\
\hline
\end{tabular}




\begin{tabular}{|c|c|c|c|c|}
\hline Lettuce (Lactuca sativa var. crispa) & $56.9-94.4 \mathrm{mg} / \mathrm{kg}$ & \multirow{3}{*}{$\begin{array}{l}\text { - Zn concentrations was lower than recommended } \\
\text { maximum limits. }\end{array}$} & \multirow{3}{*}{$\begin{array}{l}\text { wastewater-irrigated urban vegetable } \\
\text { farming sites of Addis Ababa, Ethiopia }\end{array}$} & \multirow{3}{*}{ [74] } \\
\hline $\begin{array}{l}\text { Ethiopian mustard } \quad \text { (Brassica } \\
\text { carinata A. Br) }\end{array}$ & $66.3-109 \mathrm{mg} / \mathrm{kg}$ & & & \\
\hline Beet (Beta Vulgaris var. cicla) & $77.7-129 \mathrm{mg} / \mathrm{kg}$ & & & \\
\hline Coriander & $\begin{array}{l}400 \mathrm{mg} / \mathrm{kg} \text { (leaves) } \\
172 \mathrm{mg} / \mathrm{kg} \text { (stems) } \\
203 \mathrm{mg} / \mathrm{kg} \text { (roots) }\end{array}$ & $\begin{array}{l}- \text { Wastewater irrigated sample. } \\
\text { - The concentrations of } \mathrm{Cd}, \mathrm{Pb} \text {, and } \mathrm{Zn} \text { were higher in } \\
\text { all studied vegetables (Mint, Fenugreek and coriander) } \\
\text { than the permissible limit of these metals in vegetables, } \\
\text { whereas } \mathrm{Cu} \text { was far below the tolerable limits. } \\
\text { - The } \mathrm{Zn} \text { concentration value of Mint and fenugreek } \\
\text { isn't available. The } \mathrm{Zn} \text { level is found to be highest in } \\
\text { coriander. Mint }\end{array}$ & $\begin{array}{l}\text { Government College } \\
\text { Faisalabad, Pakistan }\end{array}$ & [75] \\
\hline $\begin{array}{l}\text { Coriander (Coriandrum } \\
\text { Sativum) }\end{array}$ & $\begin{array}{l}21.4 \mathrm{mg} / \mathrm{kg} \mathrm{FW} \text { (Leaf) } \\
10.59 \mathrm{mg} / \mathrm{kg} \text { FW (Stem) }\end{array}$ & \multirow{9}{*}{$\begin{array}{l}\text { A significant portion of } \mathrm{Zn} \text { in vegetable tissues were } \\
\text { belong to "Acetic acid extractable fraction" which is } \\
\text { associated to insoluble heavy metal phosphates }\end{array}$} & \multirow{9}{*}{$\begin{array}{l}\text { Jijie Town, Gejiu city, Yunnan } \\
\text { Province, China. }\end{array}$} & \multirow{9}{*}{ [76] } \\
\hline $\begin{array}{l}\text { Chinese } \\
\text { pekinensis) }\end{array}$ cabbage $\quad$ (Brassica & $\begin{array}{l}12.40 \mathrm{mg} / \mathrm{kg} \mathrm{FW} \text { (leaf) } \\
5.13 \mathrm{mg} / \mathrm{kg} \mathrm{FW} \text { (petiole) }\end{array}$ & & & \\
\hline $\begin{array}{l}\text { Cabbage (Brassica oleracea var. } \\
\text { capitate) }\end{array}$ & $\begin{array}{l}5.95 \mathrm{mg} / \mathrm{kg} \mathrm{FW} \text { (leaf) } \\
5.65 \mathrm{mg} / \mathrm{kg} \text { (petiole) }\end{array}$ & & & \\
\hline Bok Choy (Brassica chinensis) & $\begin{array}{l}14.30 \mathrm{mg} / \mathrm{kg} \mathrm{FW} \text { (leaf) } \\
5.60 \mathrm{mg} / \mathrm{kg} \text { (petiole) }\end{array}$ & & & \\
\hline $\begin{array}{l}\text { Garlic sprout (Allium } \\
\text { ampeloprasum) }\end{array}$ & $\begin{array}{l}10.18 \mathrm{mg} / \mathrm{kg} \mathrm{FW} \text { (leaf) } \\
7.47 \mathrm{mg} / \mathrm{kg} \mathrm{FW} \text { (stem) }\end{array}$ & & & \\
\hline $\begin{array}{l}\text { Leek (Allium } \\
\text { Schoenoprasum) }\end{array}$ & $\begin{array}{l}8.63 \mathrm{mg} / \mathrm{kg} \mathrm{FW} \text { (leaf) } \\
23.98 \mathrm{mg} / \mathrm{kg} \mathrm{FW} \text { (stem) }\end{array}$ & & & \\
\hline $\begin{array}{l}\text { Green onion }(\text { Allium } \\
\text { Schoenoprasum })\end{array}$ & $\begin{array}{l}7.00 \mathrm{mg} / \mathrm{kg} \text { FW (leaf) } \\
5.97 \mathrm{mg} / \mathrm{kg} \mathrm{FW} \text { (stem) }\end{array}$ & & & \\
\hline Peppermint (Mentha haplocalyx) & $\begin{array}{l}42.81 \mathrm{mg} / \mathrm{kg} \mathrm{FW} \text { (leaf) } \\
11.58 \mathrm{mg} / \mathrm{kg} \mathrm{FW} \text { (stem) }\end{array}$ & & & \\
\hline Water spinach (Ipomoea aquatica) & $\begin{array}{l}25.77 \mathrm{mg} / \mathrm{kg} \text { (leaf) } \\
8.70 \mathrm{mg} / \mathrm{kg} \text { (stem) }\end{array}$ & & & \\
\hline
\end{tabular}

samples collected near mines and smelting plants were up to 15 times higher in $\mathrm{Zn}$ concentration compared to rural area [62]. A collective of vegetables were also been discovered to have elevated $\mathrm{Zn}$ concentration near Zhuzhou Smelter, Zhuzhou, Hunan Province, China [63].

Zn enrichment could lead to alteration in food crops' physiology. de Figueiredo et al. study has associated $\mathrm{Zn}$ exposure to $P$. vulgaris with lower phytic level [60]. Lowered phytic level could lead to increase of bioavailability of several micronutrients, including $\mathrm{Zn}$ since phytic acid is an antinutritive agent capable of blocking mineral absorption [6466]. Reduced $\mathrm{Zn}$ during pods was also observed [60].

Zn tolerance differs among plants that are closely related genetically. The physiological impact of $\mathrm{Zn}$ exposure of two related vegetable species Brassica juncea and B. napus was investigated by exposing them to varying $\mathrm{Zn}$ concentrations up to $300 \mu \mathrm{M}$. This study revealed that in term of root damage, and microelement homeostasis alteration, $B$. juncea is more $\mathrm{Zn}$ tolerant than $B$. natus. The physiology of their root was also observed. It was discovered that the oxidative components were predominant compared with nitrosative component in root [67].

The impact of $\mathrm{Zn}$ to the physiology of a food crops isn't limited to the elevation of its concentration in response of its exposure. In cooperation with other physiological significant element, varying physiological responses may be revealed. $\mathrm{Zn}(200 \mathrm{ppm})$ was coexposed with varying concentration if potassium (K) to wheat (Triticum aestivum L.). It was observed that in consequence of $\mathrm{Zn}$ and $\mathrm{K}$ co-exposure, oxidative stress was minimized, root, shoot and root lengths were improved. Another wheat physiological parameter, such as wet and dry biomass, photosynthetic pigments, osmolyte regulators and membrane stability index were also improved. Reduction of MDA content was also observed [68]. Inter-species correlation analysis on the heavy metal contents among wide range of vegetable and fruits also unveiled a strong and positive correlation between $\mathrm{Zn}$ and $\mathrm{Cd}$
[69]. $\mathrm{Zn}$ is also found to have a strong and positive relationship with $\mathrm{Fe}$ and $\mathrm{Mn}$, which are another physiological significant nutrient [70]. Zn concentration in soil has also been discovered to be one of the factor influencing Cd accumulation in cabbage [71].

The utilization of manure as fertilizers is one of the major factors impacting $\mathrm{Zn}$ availability to vegetable crops. A collective of closed greenhouse cultivated vegetables in Nanjing, China, was investigated by Chen et al. [72]. It was concluded that the $\mathrm{Zn}$ in cultivation soil was originated from chicken manure. The application of manure in agriculture isn't only contribute to elevation of heavy metal accumulation. The application of cow manure biochar was revealed to be able to reduce the bioavailability and translocation factors of several heavy metals in Zucchini (Cucurbita pepo L.), including Zn. Mining and smelting activity is another major $\mathrm{Zn}$ source for vegetable. The $\mathrm{Zn}$ level along with $\mathrm{Pb}$ and $\mathrm{Cd}$ in ribwort plantain (Plantago lanceolate L.) near mines and smelting plants were found to be enriched up to 15 times beyond rural areas in Genoa and province, Liguria, NorthWestern Italy [62]. Another studies has shown that the soil $\mathrm{Zn}$ level has been significantly enriched due to smelting activity nearby Huludao Zinc Plant, Liaoning Province, China [71].

Several recent studies have been conducted to investigate the potential human health risks of metals in vegetables. The $\mathrm{Zn}$ in Bok Choy (Brassica campestris L. ssp. chinensis Makino), Water Spinach (Ipomoea aquatica Forsk.), Shanghai green cabbage (Brassica chinensis L.), leaf lettuce (Lactuca sativa L. var. ramosa Hort.) from Shanghai, China. It was determined that the $\mathrm{Zn}$ concentrations in these vagetables were below the food safety limit set in China [73]. The $\mathrm{Zn}$ levels in Lettuce (Lactuca sativa var. crispa), Ethiopian mustard (Brassica carinata A. $\mathrm{Br}$ ) and Beet (Beta Vulgaris var. cicla) from wastewater-irrigated urban vegetable farming site in Addis Ababa, Ethiopia was also investigated for possible human health hazard. There was no $\mathrm{Zn}$ hazard discovered 
[74]. Wastewater irrigated coriander, mint and fenugreek in Faisalabad, Pakistan was found to be a potential hazard to consumers due to their higher-than- permissible-limit $\mathrm{Cd}, \mathrm{Pb}$ and $\mathrm{Zn}$ concentration [75].

It should be noted that not all of the $\mathrm{Zn}$ in a biological tissue is bioavailable. A collective of vegetables (Table 1) was sampled in Jijie Town, Gejiu city, Yunnan Province, China. It was noticed that there are a significant portion of $\mathrm{Zn}$ in vegetable tissues were categorized as insoluble metal phosphate [76]. This can be interpreted as the bioavailability of $\mathrm{Zn}$ in these vegetables may be low [77]. This factor should be taken account when the human health risk of heavy metals will be assessed.

\section{Conclusion remarks}

$\mathrm{Zn}$ is crucial for both industries and human physiology. It involves in various important biological processes. However, $\mathrm{Zn}$ would be toxic to human health in excessive concentration. Therefore, constant close monitoring of $\mathrm{Zn}$ levels in commonly consuming vegetables are crucial in public health viewpoint. The $\mathrm{Zn}$ concentration can be elevated due to the application of chicken manure fertilizer, mining and smelting activities. $\mathrm{Zn}$ in vegetable tissues were also been discovered to have a correlation with other chemical elements, such as $\mathrm{Fe}, \mathrm{Mn}$ and $\mathrm{Cd}$, indicating $\mathrm{Zn}$ enrichment could impact a vegetable by altering the level of other biologically significant elements. Finally, the human health risk assessment on $\mathrm{Zn}$ should take $\mathrm{Zn}$ speciation in food biomass into account.

\section{References}

1. Hawkes SJ (1997) What is a "heavy metal"? J Chem Educ 74: 1374.

2. Wong KW, Yap CK, Nulit R, Hamzah MS, Chen SK, et al. (2017) Effects of anthropogenic activities on the heavy metal levels in the clams and sediments in a tropical river. Environ Sci Pollut Res 24: 116-134. [Crossref]

3. Cheng WH, Yap CK (2015) Potential human health risks from toxic metals via mangrove snail consumption and their ecological risk assessments in the habitat sediment from Peninsular Malaysia. Chemosphere 135: 156-165. [Crossref]

4. Beyersmann D, Hartwig A (2008) Carcinogenic metal compounds: Recent insight into molecular and cellular mechanisms. Arch Toxicol 82: 493-512. [Crossref]

5. Depledge MH, Weels JM, Jerregaard PB (1994) Heavy metals. In: Calow P (editor.), Handb Ecotoxicol, Blackwell Science, Sheffield, pp: 543-569.

6. Badri MA, Aston SR (1983) Observations on heavy metal geochemical associations in polluted and non-polluted estuarine sediments. Environ Pollution Ser B Chem Phys 6: 181-193.

7. Hambidge M (2000) Human zinc deficiency. J Nutr 130: 1344S-9S. [Crossref]

8. Rink L, Gabriel P (2000) Zinc and the immune system. Proc Nutr Soc 59: 541-552. [Crossref]

9. Gammoh NZ, Rink L (2017) Zinc in Infection and Inflammation. Nutrients 9. [Crossref]

10. Prasad AS, Sandstead HH, Schulert AR, El Rooby AS (1963) Urinary excretion of zinc in patients with the syndrome of anemia, hepatosplenomegaly, dwarfism, and hypogonadism. J Lab Clin Med 61: 537-549. [Crossref]

11. Valberg LS, Flanagan PR, Chamberlain MJ (1984) Effects of iron, tin, and copper on zinc absorption in humans. Am J Clin Nutr 40: 536-541. [Crossref]

12. Favier A, Favier M (1990) Effects of zinc deficiency in pregnancy on the mother and the newborn infant. Rev Fr Gynecol Obstet 85: 13-27. [Crossref]

13. Institute of Medicine of the National Academies (2011) DRI: dietary reference intakes of calcium and vitamin D. The National Academies Press, Washington, D.C.

14. World Health Organization (1996) Trace elements in human nutrition and health. Geneva, Switzerland.

15. EFSA Panel on Dietetic Products Nutrition and Allergies (2014) Scientific opinion on dietary reference values for zinc. EFSA $J$ 12: 3844 .

16. Coleman JE (1992) Structure and mechanism of alkaline phosphatase. Annu Rev Biophys Biomol Struct 21: 441-483. [Crossref]
17. Coleman JE (1992) Zinc proteins: Enzymes, storage proteins, transcription factors, and replication proteins. Annu Rev Biochem 61: 897-946. [Crossref]

18. Andreini C, Banci L, Bertini I, Rosato A (2006) Counting the zinc-proteins encoded in the human genome. J Proteome Res 5: 196-201. [Crossref]

19. Krężel A, Maret W (2016) The biological inorganic chemistry of zinc ions. Arch Biochem Biophys 611: 3-19. [Crossref]

20. Maret W (2010) Metalloproteomics, metalloproteomes, and the annotation of metalloproteins. Metallomics 2: 117-125. [Crossref]

21. Wessels I, Maywald M, Rink L (2017) Zinc as a gatekeeper of immune function. Nutrients 9. [Crossref]

22. Maywald M, Wessels I, Rink L (2017) Zinc Signals and Immunity. Int J Mol Sci 18. [Crossref]

23. DeCoursey TE, Morgan D, Cherny VV (2003) The voltage dependence of NADPH oxidase reveals why phagocytes need proton channels. Nature 422: 531-534. [Crossref]

24. Hasegawa H, Suzuki K, Suzuki K, Nakaji S, Sugawara K (2000) Effects of zinc on the reactive oxygen species generating capacity of human neutrophils and on the serum opsonic activity in vitro. Luminescence 15: 321-327. [Crossref]

25. Brinkmann V, Reichard U, Goosmann C, Fauler B, Uhlemann Y, et al. (2004) Neutrophil extracellular traps kill bacteria. Science 303: 1532-1535. [Crossref]

26. Lee S, Eskin SG, Shah AK, Schildmeyer LA, McIntire L V (2012) Effect of zinc and nitric oxide on monocyte adhesion to endothelial cells under shear stress. Ann Biomed Eng 40: 697-706. [Crossref]

27. Zhou X, Fragala MS, McElhaney JE, Kuchel GA(2010) Conceptual and methodological issues relevant to cytokine and inflammatory marker measurements in clinical research. Curr Opin Clin Nutr Metab Care 13: 541-547. [Crossref]

28. Costarelli L, Muti E, Malavolta M, Cipriano C, Giacconi R, et al. (2010) Distinctive modulation of inflammatory and metabolic parameters in relation to zinc nutritional status in adult overweight/obese subjects. J Nutr Biochem 21: 432-437. [Crossref]

29. Foster M, Samman S (20120 Zinc and Regulation of inflammatory cytokines: Implications for cardiometabolic disease. Nutrients 4: 676-694. [Crossref]

30. Bao B, Prasad AS, Beck FWJ, Snell D, Suneja A, et al. (2008) Zinc supplementation decreases oxidative stress, incidence of infection, and generation of inflammatory cytokines in sickle cell disease patients. Transl Res 152: 67-80. [Crossref]

31. Summersgill H, England H, Lopez-Castejon G, Lawrence CB, Luheshi NM, et al (2014) Zinc depletion regulates the processing and secretion of IL-1 $\beta$. Cell Death Dis 5: e1040. [Crossref]

32. Sales MC, de Oliveira LP, de Araújo Cabral NL, de Sousa SES, das Graças Almeida M, et al. (2018) Plasma zinc in institutionalized elderly individuals: Relation with immune and cardiometabolic biomarkers. J Trace Elem Med Biol 50: 615-621. [Crossref]

33. Olechnowicz J, Tinkov A, Skalny A, Suliburska J (2018) Zinc status is associated with inflammation, oxidative stress, lipid, and glucose metabolism. J Physiol Sci 68: 19-31. [Crossref]

34. Hadwan MH, Almashhedy LA, Alsalman ARS (2014) Study of the effects of oral zinc supplementation on peroxynitrite levels, arginase activity and NO synthase activity in seminal plasma of Iraqi asthenospermic patients. Reprod Biol Endocrinol 12: 1. [Crossref]

35. Ogawa D, Asanuma M, Miyazaki I, Tachibana H, Wada J, et al. (2011) High glucose increases metallothionein expression in renal proximal tubular epithelial cells. Exp Diabetes Res 2011: 534872. [Crossref]

36. Oteiza PI (2012) Zinc and the modulation of redox homeostasis. Free Radic Biol Med 53: 1748-1759. [Crossref]

37. Skalny AA, Tinkov AA, Medvedeva YS, Alchinova IB, Karganov MY, et al. (2015) Effect of short-term zinc supplementation on zinc and selenium tissue distribution and serum antioxidant enzymes. Acta Sci Pol Technol Aliment 14: 269-276. [Crossref]

38. Li HT, Jiao M, Chen J, Liang Y (2010) Roles of zinc and copper in modulating the oxidative refolding of bovine copper, zinc superoxide dismutase. Acta Biochim Biophys Sin (Shanghai) 42: 183-194. [Crossref]

39. Muthuraman P, Ramkumar K, Kim DH (2014) Analysis of dose-dependent effect of zinc oxide nanoparticles on the oxidative stress and antioxidant enzyme activity in adipocytes. Appl Biochem Biotechnol 174: 2851-2863. [Crossref]

40. Pandurangan M, Veerappan M, Kim DH (2015) Cytotoxicity of zinc oxide nanoparticles on antioxidant enzyme activities and mRNA expression in the cocultured $\mathrm{C} 2 \mathrm{C} 12$ and 3T3-L1 cells. Appl Biochem Biotechnol 175: 1270-1280. [Crossref] 
41. Nazarizadeh A, Asri-Rezaie S (2016) Comparative study of antidiabetic activity and oxidative stress induced by zinc oxide nanoparticles and zinc sulfate in diabetic rats. AAPS PharmSciTech 17: 834-843. [Crossref]

42. El-Ashmony SMA, Morsi HK, Abdelhafez AM (2011) Effect of zinc supplementation on glycemic control, lipid profile, and renal functions in patients with type II diabetes: A single blinded, randomized, placebo-controlled, trial. Journal of Biology, Agriculture and Healthcare 2: 33-41.

43. Stene MC, Frikke-Schmidt R, Nordestgaard BG, Tybjaerg-Hansen A (2006) Zinc finger protein 202, genetic variation, and HDL cholesterol in the general population. $J$ Lipid Res 47: 944-952. [Crossref]

44. Wagner S, Hess MA, Ormonde-Hanson P, Malandro J, Hu H, et al. (2000) A broad role for the zinc finger protein ZNF202 in human lipid metabolism. J Biol Chem 275: 15685-15690. [Crossref]

45. Tinkov AA, Popova E V, Gatiatulina ER, Skalnaya AA, Yakovenko EN, et al. (2016) Decreased adipose tissue zinc content is associated with metabolic parameters in high fat fed Wistar rats. Acta Sci Pol Technol Aliment 15: 99-105. [Crossref]

46. Roth HP, Kirchgessner M (1981) Zinc and insulin metabolism. Biol Trace Elem Res 3: 13-32. [Crossref]

47. Jayawardena R, Ranasinghe P, Galappatthy P, Malkanthi R, Constantine G, et al. (2012) Effects of zinc supplementation on diabetes mellitus: a systematic review and metaanalysis. Diabetol Metab Syndr 4: 13. [Crossref]

48. Yang HK, Lee SH, Han K, Kang B, Lee SY, et al. (2015) Lower serum zinc levels are associated with unhealthy metabolic status in normal-weight adults: The 2010 Korea national health and nutrition examination survey. Diabetes Metab 41: 282-290. [Crossref]

49. Ranasinghe P, Pigera S, Galappatthy P, Katulanda P, Constantine GR (2015) Zinc and diabetes mellitus: understanding molecular mechanisms and clinical implications. DARU J Pharm Sci 23: 44. [Crossref]

50. Dunn MF (2005) Zinc-ligand interactions modulate assembly and stability of the insulin hexamer - A review. BioMetals 18: 295-303. [Crossref]

51. Egefjord L, Petersen AB, Rungby J (2010) Zinc, alpha cells and glucagon secretion. Curr Diabetes Rev 6: 52-57. [Crossref]

52. Hegazi SM, Ahmed SS, Mekawwy AA, Mortagy MS, Abdel-Kadder M (1992) Effect of zinc supplementation on serum glucose, insulin, glucagon, glucose-6-phosphatase, and mineral levels in diabetics. J Clin Biochem Nutr 12: 209-215.

53. Terrin G, Berni Canani R, Di Chiara M, Pietravalle A, Aleandri V, et al. (2015) Zinc in early life: A key element in the fetus and preterm neonate. Nutrients 7: 10427-10446. [Crossref]

54. Hooper PL, Visconti L, Garry PJ, Johnson GE (1980) Zinc lowers high-density lipoprotein-cholesterol levels. JAMA 244: 1960-1961. [Crossref]

55. Barceloux DG (1999) Zinc. J Toxicol Clin Toxicol 37: 279-292. [Crossref]

56. Mohammad MK, Zhou Z, Cave M, Barve A, McClain CJ (2012) Zinc and liver disease. Nutr Clin Pract 27: 8-20. [Crossref]

57. Nriagu J (2011) Zinc toxicity in humans. Encycl Environ Heal 2011: 801-807.

58. Chandra RK (1984) Excessive intake of zinc impairs immune responses. JAMA 252: 1443-1446. [Crossref]

59. Devine CM, Connors M, Bisogni CA, Sobal J (1998) Life-course influences on fruit and vegetable trajectories: Qualitative analysis of food choices. J Nutr Educ 30: 361370.

60. de Figueiredo MA, Boldrin PF, Hart JJ, de Andrade MJB, Guilherme LRG, et al. (2017) Zinc and selenium accumulation and their effect on iron bioavailability in common bean seeds. Plant Physiol Biochem 111: 193-202. [Crossref]

61. Reboredo F, Simões M, Jorge C, Mancuso M, Martinez J, et al. (2019) Metal content in edible crops and agricultural soils due to intensive use of fertilizers and pesticides in Terras da Costa de Caparica (Portugal). Environ Sci Pollut Res Int 26: 2512-2522. [Crossref]
62. Drava G, Cornara L, Giordani P, Minganti V (2019) Trace elements in Plantago lanceolata L., a plant used for herbal and food preparations: new data and literature review. Environ Sci Pollut Res 26: 2305-2313. [Crossref]

63. Li X, Li Z, Lin CJ, Bi X, Liu J, et al. (2018) Health risks of heavy metal exposure through vegetable consumption near a large-scale $\mathrm{Pb} / \mathrm{Zn}$ smelter in central China. Ecotoxicol Environ Saf 161: 99-110. [Crossref]

64. Singh B, Kunze G, Satyanarayana T (2011) Developments in biochemical aspects and biotechnological applications of microbial phytases. Biotechnol Mol Biol Rev 63: 6987.

65. Urbano G, López-Jurado M, Aranda P, Vidal-Valverde C, Tenorio E, et al. (2000) The role of phytic acid in legumes: antinutrient or beneficial function? J Physiol Biochem 56: 283-294. [Crossref]

66. Feil B (2001) Phytic acid. J New Seeds 3: 1-35.

67. Feigl G, Lehotai N, Molnár Á, Ördög A, Rodríguez-Ruiz M, et al. (2015) Zinc induces distinct changes in the metabolism of reactive oxygen and nitrogen species (ROS and RNS) in the roots of two Brassica species with different sensitivity to zinc stress. Ann Bot 116: 613-625. [Crossref]

68. Jan AU, Hadi F, Midrarullah, Nawaz MA, Rahman K (2017) Potassium and zinc increase tolerance to salt stress in wheat (Triticum aestivum L.). Plant Physiol Biochem 116: 139-149. [Crossref]

69. Parveen Z, Khuhro MI, Rafiq N (2003) Market basket survey for lead, cadmium, copper, chromium, nickel, and zinc in fruits and vegetables. Bull Environ Contam Toxicol 71: 1260-1264.

70. Shukla S, Bhargava A, Chatterjee A, Srivastava J, Singh N, et al. (2006) mineral profile and variability in vegetable Amaranth (Amaranthus tricolor). Plant Foods Hum Nutr 61: $23-28$.

71. Li B, Wang Y, Jiang Y, Li G, Cui J, et al. (2016) The accumulation and health risk of heavy metals in vegetables around a zinc smelter in northeastern China. Environ Sci Pollut Res Int 23: 25114-25126. [Crossref]

72. Chen Y, Huang B, Hu W, Weindorf DC, Yang L (2013) Environmental assessment of closed greenhouse vegetable production system in Nanjing, China. J Soils Sediments 13: 1418-1429.

73. Bi C, Zhou Y, Chen Z, Jia J, Bao X (2018) Heavy metals and lead isotopes in soils, road dust and leafy vegetables and health risks via vegetable consumption in the industrial areas of Shanghai, China. Sci Total Environ 619-620: 1349-1357. [Crossref]

74. Woldetsadik D, Drechsel P, Keraita B, Itanna F, Gebrekidan H (2017) Heavy meta accumulation and health risk assessment in wastewater-irrigated urban vegetable farming sites of Addis Ababa, Ethiopia. Int J Food Contam 4: 9.

75. Anwar S, Nawaz MF, Gul S, Rizwan M, Ali S, et al. (2016) Uptake and distribution of minerals and heavy metals in commonly grown leafy vegetable species irrigated with sewage water. Environ Monit Assess 188: 541. [Crossref]

76. Li Y, Wang H, Wang H, Yin F, Yang X, et al. (2014) Heavy metal pollution in vegetables grown in the vicinity of a multi-metal mining area in Gejiu, China: total concentrations, speciation analysis, and health risk. Environ Sci Pollut Res 21: 12569-12582. [Crossref]

77. Qiu Q, Wang Y, Yang Z, Yuan J (2011) Effects of phosphorus supplied in soil on subcellular distribution and chemical forms of cadmium in two Chinese flowering cabbage (Brassica parachinensis L.) cultivars differing in cadmium accumulation. Food Chem Toxicol 49: 2260-2267. [Crossref]

78. Eissa MA (2019) Effect of cow manure biochar on heavy metals uptake and translocation by zucchini (Cucurbita pepo L). Arab J Geosci 12: 48

79. Dong J, Yang Q, Sun L, Zeng Q, Liu S, et al. (2011) Assessing the concentration and potential dietary risk of heavy metals in vegetables at a $\mathrm{Pb} / \mathrm{Zn}$ mine site, China. Environ Earth Sci 64: 1317-1321.

80. Bae YJ, Kim MH, Lee JH, Choi MK (2015) Analysis of six elements (Ca, Mg, Fe, Zn, $\mathrm{Cu}$, and $\mathrm{Mn}$ ) in several wild vegetables and evaluation of their intakes based on Korea national health and nutrition examination survey 2010-2011. Biol Trace Elem Res 164 114-121. [Crossref]

Copyright: (C2019 Wong KW. This is an open-access article distributed under the terms of the Creative Commons Attribution License, which permits unrestricted use, distribution, and reproduction in any medium, provided the original author and source are credited. 